\title{
Between active seekers and non-users: segments of science-related media usage in Switzerland and Germany
}

Metag, Julia ; Maier, Michaela ; Füchslin, Tobias ; Bromme, Laurits ; Schäfer, Mike S

\begin{abstract}
Citizens' attitudes toward science are related to their use of science-related information from various sources. Evidence is scarce regarding citizens' individual media repertoires for staying informed about science as segmentation studies so far have primarily focused on scientific attitudes. In this paper, we explore audience segments regarding their science-related information behavior and whether such segments are comparable or vary between two countries with similar information environments. Based on two surveys in Switzerland and Germany, we identify national audience segments that differ in their science-related information repertoires, and analyze their sociodemographic characteristics and science-related attitudes. In both countries, we find very comparable information user segments ranging from those who inform themselves frequently about science ("Active Seekers"/"Science Consumers") to those who hardly get in contact with any information about science and research ("Non-Users"). Those segments which get in contact with information about science frequently show generally more positive attitudes.
\end{abstract}

DOI: https://doi.org/10.1080/17524032.2018.1463924

Posted at the Zurich Open Repository and Archive, University of Zurich

ZORA URL: https://doi.org/10.5167/uzh-159001

Journal Article

Accepted Version

Originally published at:

Metag, Julia; Maier, Michaela; Füchslin, Tobias; Bromme, Laurits; Schäfer, Mike S (2018). Between active seekers and non-users: segments of science-related media usage in Switzerland and Germany. Environmental Communication, 12(8):1077-1094.

DOI: https://doi.org/10.1080/17524032.2018.1463924 


\title{
Accepted Author Manuscript
}

\section{Between Active Seekers and Non-Users.}

\section{Segments of Science-Related Media Usage in Switzerland and Germany}

\section{Julia Metag, Michaela Maier, Tobias Füchslin, Laurits Bromme \& Mike S. Schäfer}

To cite this article: Julia Metag, Michaela Maier, Tobias Füchslin, Laurits Bromme \& Mike S. Schäfer (2018) Between Active Seekers and Non-Users: Segments of Science-related Media Usage in Switzerland and Germany, Environmental Communication, 12:8, 1077-1094, DOI: $10.1080 / 17524032.2018 .1463924$

To link to this article: $\underline{\text { htps://doi.org/10.1080/17524032.2018.1463924 }}$

\begin{abstract}
Citizens' attitudes towards science are related to their use of science-related information from various sources. Evidence is scarce regarding citizens' individual media repertoires for staying informed about science as segmentation studies so far have primarily focused on scientific attitudes. In this paper, we explore audience segments regarding their science-related information behavior and whether such segments are comparable or vary between two countries with similar information environments. Based on two surveys in Switzerland and Germany, we identify national audience segments that differ in their sciencerelated information repertoires, analyze their sociodemographic characteristics and sciencerelated attitudes. In both countries, we find very comparable information user segments ranging from those who inform themselves frequently about science ("Active Seekers"/ "Science Consumers") to those who hardly get in contact with any information about science and research ("Non-Users"). Those segments which get in contact with information about science frequently show generally more positive attitudes.
\end{abstract}




\section{Introduction}

Science is seemingly full of wonders: Researchers explore the origins of the universe, aim to cure terminal diseases, engineer human DNA, work on better ways to curtail greenhouse gas emissions etc. Today, science is understood as being contextualized in society and often being co-produced by scientists with partners from economy, politics, civil society etc. (e.g. Jasanoff, 2011). Science thus forms an integral part of our society with scientists, economic and political actors as well as citizens, among others, taking up important roles when the societal support for science is concerned. For example, science depends on the support of political authorities for scientists' freedom to pursue the research questions that they regard as important. And it depends on tax payers' acceptance of expenditures and liberties, and on their general support for science.

Latest research has shown that citizens' support for science strongly depends on their interest, trust and general (positive) attitudes towards research (Besley, 2016). These aspects are, again, strongly related to science communication, as many citizens (i.e. people who do not have personal contacts with the system of science) mainly encounter science via communication, for example in news media, online, in social media, in museums, participating in science cafes or other science-related events. Science communication research analyzes how citizens acquire information about science, its processes and findings, and in how far this information is relevant for the formation of their science-related attitudes (for a summary see, e.g. Authors, 2014). However, when it comes to the question of which sources citizens use to stay informed about ongoing research, evidence is more scarce, especially with regard to individual media repertoires. Thus, the question which individual combination of journalistic offline and online media, online sources or social media citizens use to gather science-related information, has become even more pressing in times of online communication in which the monopoly of science journalism has long vanished (e.g. Büchi, 2017; Jia et al., 2017; Authors, 2017; Su et al., 2017). Yet, segmentation studies in science 
communication so far have primarily focused on audience segments with regards to scientific attitudes (Authors, 2017; Kawamoto et al., 2013; OST, 2005; OST \& Welcome Trust, 2000; Research Councils UK, 2008; Rothmund et al., 2017). In some of these studies, we find first evidence that these segments also show distinct patterns of information behavior (e.g. Guenther \& Weingart, 2017; Kawamoto et al., 2013). However, these studies either do not focus specifically on science-related information (Kawamoto et al., 2013) or only integrate a limited number of information sources (Guenther \& Weingart, 2017). Therefore, in this paper, we contribute to research on citizens' science-related information behavior in four ways: For the first time, we aim at identifying audience segments that differ in their science-related information repertoires, taking news media sources, their online equivalents, but also other online sources and social media into account. By focusing on citizens' general science-related information repertoires, we gain insight into segments of overall science media use which are more generalizable and not limited to a certain scientific topic which individuals might be especially interested in (e.g. climate change, GMO). We thus deliver insights into the general ways in which citizens get information and orientation about scientific issues, which may feed into their overall perceptions of science as a social system, and into their systemic trust (Authors, 2016). Second, we analyze the sociodemographic characteristics of these audience segments, and, third, investigate whether they differ in their science-related attitudes. Fourth, we compare these structures in two countries, i.e. Germany and Switzerland, applying a mostsimilar cases design to overcome the specificity of one nation state and test the generality of information segments across countries (Esser \& Hanitzsch, 2012). Such studies comparing audience structures in similar and varying information environments are missing in the field of science information usage so far. 


\section{The Relevance of Science Information User Segments}

Distinguishing different segments of the population - like different types of media users - has a long tradition in social science (Smith, 1956). Commonly, this was done via segmentation analyses that aimed to "divide the general public into relatively homogeneous, mutually exclusive subgroupings" (Hine et al., 2014, p. 442; cf. Lotenberg, Schechter, \& Strand, 2011, p. 125). These analyses had also often the intent to develop tailored communication strategies with which attitudes and behaviors of these subgroups could be influenced subsequently (Slater, 1996).

Segmentation analyses have used three general logics for the selection of relevant variables and the identification of audience segments or user types: Early approaches often used sociodemographic and geographic location variables to identify audience segments (Slater, 1996). The audience segments that were reconstructed in this way were later compared with regards to their media use, their attitudes or their consumer behavior (Dibb \& Simkin, 2009). Such an approach is only useful in those rare cases, however, when sociodemographic or sociogeographic variables are strongly linked to attitudinal or behavioral patterns (Yankelovich \& Meer, 2006, 123f.).

Therefore, some of the recent studies based their segmentation analyses on peoples' attitudes towards a certain object, i.e. on "psychographic" variables (Wind, 1978, 319f.). These incorporated cognitive elements like knowledge, affective elements as well as behavioral elements of attitudes (e.g. Hine et al., 2014; Sütterlin et al., 2011; Authors, 2018).

These segmentation analyses have drawn criticism as well, however. Scholars have argued that while psychographically rooted analyses "may capture some truth about real people's lifestyles, attitudes, self-images and aspirations, [they] are weak at predicting" peoples' behavior" (Yankelovich \& Meer, 2006, p. 124) and thus segmentation analyses should be based on behavioral variables (Yankelovich \& Meer, 2006), for example around 
peoples' patterns of media and information use (cf. Lotenberg et al., 2011). After all, identifying population segments that are homogenous in their patterns of media and information use would have the potential to improve communication efforts and to facilitate better targeted messages (Noar et al., 2007).

\section{Audience Segments, Sociodemographic Differences and Attitudes Towards Science}

What segments of citizens exist with regards to science-related information use? The studies by Kawamoto et al. (2013) and Guenther \& Weingart (2017) identified different segments of the Japanese and South African populations with regards to their attitudes towards science, sociodemographics and their media use. By including media use in their segmentation analyses, they could show that certain segments of the public use information about science significantly more than others (e.g. the "Sciencephiles" in Japan; Kawamoto et al., 2013; or the "Urban, moderately to high literate, and highly educated" in South Africa; Guenther \& Weingart, 2017). These studies, however, either do not include specific sciencerelated information use but only general news usage (Kawamoto et al., 2013), or do not segment the public solely or even primarily based on their science-related media and information use and include only a limited number of information sources (Guenther \& Weingart, 2017; Kawamoto et al., 2013). However, only if one identifies audience segments based on their scientific media and information use one is able to differentiate information repertoires in the public (cf. Hasebrink \& Popp, 2006) and to provide information for science advocates which helps them improve their communication efforts. The reconstruction of segment-specific combinations of media and information sources is particularly relevant in times of individualized content selection and curation.

As of now, such studies, which have segmented the population according to their media and information use, only exist for issues other than science, mostly general news use. 
A recent study found that the German public can be divided into four segments with regards to their information use (Mangold et al., 2017). One segment focuses on traditional and particularly regional news media, the second one relies on entertainment-oriented media, the third on quality media, i.e. public service broadcasting and broadsheets, and the fourth on online media in its news diet (Mangold et al., 2017). A study in Switzerland found similar segments, among them such which rely more on traditional, offline mass media, and segments that are strongly oriented towards online media, such as the "Global Surfers" (Schneider \& Eisenegger, 2016). The Swiss study also showed that audience segments not only differ with regards to the kind of news media they use, but also with regards the frequency of use. Also, they found the segment of the "News Deprived", i.e. of people who use news media considerably less frequently than all other segments (Schneider \& Eisenegger, 2016).

We assume that the general patterns related to the use of traditional mass media versus online media and to the frequency of use also apply to science-related information use. We can thus derive two hypotheses with regards to our first research aim:

Hla: Audience segments of science information use will differ with regard to whether they use more traditional journalistic mass media or more online media.

H1b: Audience segments of science information use will differ with regards to the frequency of their use of scientific information.

However, apart from these general tendencies of online and offline science media use, audience segments of science information use may reveal more nuanced differences than segments of general news use. There are many possibilities for people to inform themselves about science - ranging from general news media, which also cover science issues, to specific science magazines. Particularly on the Internet, the information sources available are very diverse. The media ecosystem with regards to science has changed particularly strongly because science journalism today faces major challenges (e.g., economically; Authors, 2017) 
and online media has altered the landscape for information about science in general (Brossard, 2013).

In addition, we expect to find sociodemographic differences between people belonging to different science-related information user segments as previous studies have established a link between sociodemographic characteristics and patterns of media and information use (e.g. Nisbet, Scheufele, Shanahan, Moy et al., 2002). With regards to age, a German survey found that older people more often use scientific content in print media or on television but are less likely to look for it on the Internet (Wissenschaft im Dialog, 2016). Research also found gender differences with women using all kinds of media less often than men (Nisbet, Scheufele, Shanahan, Moy et al., 2002). In Germany, women were less likely to watch television shows about science and or to get information about science on the Internet (Wissenschaft im Dialog, 2016). Education positively influences newspaper use, science magazine and science television use, and the use of the Internet and social media in countries like the US, Germany and South Korea (Chang et al., 2017; Nisbet et al., 2002; Wissenschaft im Dialog, 2016). Based on these findings, we expect the following differences:

H2a: Audience segments that use primarily online communication about science are on average younger than segments using primarily traditional mass media.

H2b: Audience segments that use primarily online communication about science include on average less women than segments using primarily traditional mass media.

H2c: Audience segments with intensive use of science information across all kinds of media are higher educated than segments with lower science information use.

As a third step, we investigate whether the audience segments differ in their sciencerelated attitudes. As the segmentation analyses by Kawamoto et al. (2013) and Guenther \& Weingart (2017) have shown, attitudes towards science and science-related media use are correlated. Audience segments with a higher interest in science, higher scientific literacy, and 
belief in the benefits of science are also the ones getting in contact with it through online and offline media most frequently. This is underscored by most of the media effects research in science communication revealing that media use in general can increase individuals' interest in science and also, to a certain degree, their scientific literacy (Nisbet et al., 2002; Zhao, 2009). Media use about scientific issues is also related to positive attitudes towards science, support for specific scientific developments as well as trust in science (Anderson, Scheufele, Brossard, \& Corley, 2012; Dudo et al., 2011; Nisbet et al., 2002; Scheufele \& Lewenstein, 2005). On this basis, we hypothesize:

H3: Audience segments with a more frequent use of scientific information across all channels are more interested in science, more scientific literate and hold more positive attitudes towards science.

\section{Media coverage of science in Switzerland and Germany}

The fourth aim of this paper is to initiate research on the question whether such audience segments are universal or vary, e.g., depending on information environments, a strand missing in science communication research so far. As a first step, we compare the structures in two similar countries, i.e. Switzerland and Germany. Such a most similar cases design is appropriate to overcome the specificity of one nation state and test to the generality of the information segments (Esser \& Hanitzsch, 2012; Livingstone, 2003). To test whether the two countries qualify for a most similar cases design, we compare not only their general media systems but also the characteristics of the two national information environments with regards to science-related information.

In general, the media structures in both countries can be best described by the characteristics of the so-called democratic corporatist model (Hallin \& Mancini, 2004), e.g. having (still) relatively high newspaper circulations, a pluralist national press with strong professionalization, self-regulation and press freedom as well as strong public-service 
broadcasting. Also, Mejlgaard (2017, p.8) has described science as "central" for the sciencesociety relationship in both countries, with consolidated science communication, inclusion of publics in the governance of science and transfer of scientific findings to policy-makers. Regarding the relevance of science coverage within both media systems, we look at the number of journalists active in the field, the amount and tone of media coverage devoted to science and the share of audience. The "Worlds of Journalism" project (Hanusch \& Hanitzsch, 2017) shows that about four percent of journalists in both countries work for science and education desks in their media (Dingerkus, Keel \& Wyss, personal information; Steindl, Lauerer, \& Hanitzsch, 2017). Looking at the attention general media grant to science topics, we find for both countries that, e.g., public broadcasters allocate between three and six percent of their total airtime to "culture and science" (fög, 2017; Reitze, 2016). Of course, science topics make up a considerable portion of the print market (e.g. books) and attract the attention of up to ten percent of newspaper readers in both countries alike (fög, 2017; Reitze, 2016). However, weighted for the total reach of newspapers, the numbers converge to the figure of about five percent of the media coverage and usage in both countries being devoted to and attracted by science topics.

Regarding journalists' self-assessed motives and roles, findings show that Swiss and German journalists alike find objectivity of reporting to be their most important goal $\left(m_{\text {Switzerland }}=4.53 ; m_{\text {Germany }}=4.59 ; \mathrm{p}>0.05 ;\right.$ see Hanitzsch, Steindl \& Lauerer, 2016, p. 2; Dingerkus, Keel \& Wyss, 2016, p. 2; also see Authors, 2016). And concerning the tonality of coverage of science topics, which seems to be neutral to slightly positive in general, the few analyses at hand suggest that there is probably more variation regarding the evaluation of specific scientific topics than between the general coverage of science in the two countries under observation (Eisenegger \& Gedamke, 2013; Hömberg \& Yankers, 2000; Milde \& Ruhrmann, 2006). 
In sum, Switzerland and Germany seem appropriate for a most similar cases study, as the science-related media coverage in both countries and its usage are similarly pronounced. In addition, (science) journalists in both countries seem to hold similar perceptions of the own roles which seem to lead to a usually neutral to slightly positive tone of the media reports on science-related topics. Therefore, we hypothesize:

H4: Segments of science-related media usage will be similar in Switzerland and Germany.

\section{Methods}

Data

In the case of Switzerland, we will use data from a telephone survey conducted in 2016 by the market research institute $X$ (blinded for review). It assesses citizens' information behavior as well as attitudes towards, beliefs in and knowledge about science. The sample was based on a random quota sampling procedure. First, telephone numbers were drawn randomly from all listed numbers of private households (including 5\% mobile phone numbers). Second, quotas for age and gender combined were used to select participants. 1,051 respondents participated (651 in German-, 200 in French- and 200 in Italian-speaking Switzerland). $51 \%$ were women, the mean age was 46 years $(\mathrm{SD}=17.9)$ and $27 \%$ had a university degree (see also Table 1). For the analyses the sample was weighted regarding cantons, size of living area, education, occupation and household size.

For Germany, we draw on data from an online survey on citizens' science-related information behavior and attitudes fielded in 2016 as part of the DFG special priority program 1409 "Science and the Public". The sample consists of 1,997 respondents recruited by the private sampling provider $\mathrm{X}$ (blinded for review) and represents the German adult population concerning age, gender, education and region (Authors, 2017). The average age was 45 years $(\mathrm{SD}=14.0), 50 \%$ were female and $16 \%$ had a university degree (see also Table 1$)$. The 
German sample was drawn from an online panel but participants in the panel were recruited online and offline. As participants for the Swiss study were recruited offline, while the German sample was recruited online and offline, the results might be biased in the sense that online media usage might be overestimated in Germany. This has to be taken into account when interpreting the findings. Regarding sociodemographic variables, both samples are representative for their respective country and possible differences should not affect the overall patterns of science information repertoires.

\section{Measurements}

We used various measures of media and information usage on which we base our segmentation analysis (an overview of all measures and their descriptives can be found in Table 1). In both countries, the frequency of use of traditional media for information about science (television, newspapers/magazines, and science magazines) as well as the usage of different online channels are included in the segmentation analysis (e.g BBVA foundation, 2011; Pew Research Center, 2013).

In order to enrich the description of the identified segments, we analyzed to what extent participants get in contact with science on other occasions such as visits in museums, zoos, aquariums, science-related events, or through non-fiction books (e.g. OST \& The Welcome Trust, 2001). We also describe segments with regards to their sociodemographic characteristics (age, sex and education, see Besley, 2013), religiosity (OST \& The Welcome Trust, 2001), political orientation (Nisbet et al., 2002) and an index of people's personal or professional proximity to science (BBVA foundation, 2011). Furthermore, we measured interest in science (e.g. Eurobarometer, 2010), scientific literacy and trust in science (Lee et al., 2005; for all these variables see also Table 1) as attitudinal variables. People's scientific 
literacy was calculated as a sum index consisting of eight true/false questions. We assigned one point for correct answers, for wrong or no answers, people were attributed zero points.

The continents on which we live have been moving for millions of years. (correct)

Electrons are smaller than atoms. (correct)

Antibiotics kill viruses as well as bacteria. (false)

The genes of the mother decide if the child will be a boy or a girl. (false)

Sunscreen protects the skin from ultraviolet rays. (correct)

[German survey: Sunscreen protects the skin from infrared rays. (false)]

Water boils faster in high altitudes. (correct)

It is possible to change the genes of human embryos. (correct)

[German survey: It is not yet possible to change the genes of human embryos. (false)]

Scientific theories never change. (false)

\section{[Table 1 about here]}

\section{Logic of Analysis}

To identify population segments, we ran separate latent class analyses (LCA) in both countries. LCA has several advantages: Unlike most distance-based methods, it can handle any variable level, large numbers of variables (Magidson \& Vermunt, 2004; McLachlan \& Peel, 2005) and also single missing values (Maibach et al., 2006). Since cluster solutions are based on a statistical model, measures to compare model fit such as BIC can be used and the predictive power of indicators is denoted (Linzer \& Lewis, 2011). 
For each country, we used ten media source variables and computed optimized segment-solutions from one up to ten ${ }^{1}$ segments using LatentGold 5.1 software (Vermunt \& Magidson, 2016). For each model, we entered 5000 random sets of starting values into the algorithm to ensure validity and robustness of each solution. All further specifications are available within the supplemental materials. The final solutions were determined by first looking at BIC values, then taking face validity of segment profiles into account. To assess group means, modal attribution was used to assign individual cases to segments according to their maximum likelihood estimation.

\section{Results}

User Segments in Switzerland and Germany

For the Swiss public, BIC values pointed to five segments as the most favorable solution, closely followed by six and four segments (see Online Appendix). As the fivesegment solution also offered a clear interpretation, we chose it as our solution for Switzerland (see Figure 1 and Table 3 of the Appendix).

In order to estimate the precision of classification we calculated the overall hit rate. It is defined as the sample mean of all respondents' modal posterior probabilities (cf.

Gollwitzer, 2012). For the Swiss sample, the hit rate was $\mathrm{T}=0.81$. For $99 \%$ of cases, the likelihood of belonging to one of the five segments exceeded $40 \%$ and no single case was indecisive.

\footnotetext{
${ }^{1}$ In the case of Germany, we went up to fourteen segments, since ten segments were not enough to draw a clear conclusion regarding the optimal number of segments (see Online Appendix).
} 


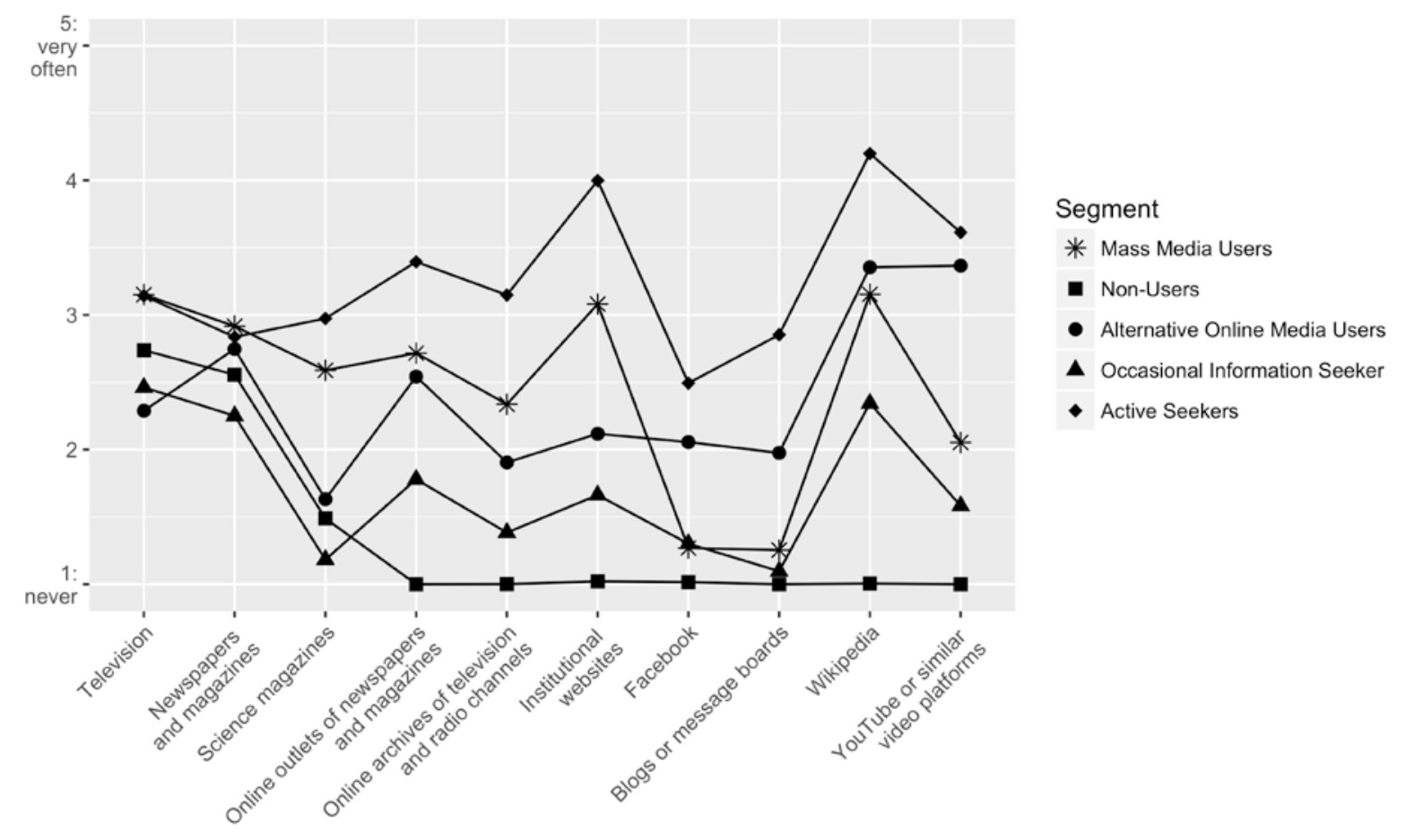

- The "Active Seekers" $(n=152,14.49 \%)$ form the smallest segment of the Swiss population. They get in contact with science-related information most frequently across all kinds of media. They use news media regularly but are also the most avid readers of science magazines. On the Internet, they look for reputable sources of information by using websites of scientific institutions and Wikipedia most often. Also, Youtube channels are being used quite regularly by members of this segment. This information pattern indicates that people in this segment probably search quite actively for information about science offline (e.g. in science magazines), but particularly online.

- The "Mass Media Users" $(n=262,24.96 \%)$ are the largest segment of the Swiss population and similar to the "Active Seekers" in their information patterns with regards to traditional media. They use traditional mass media quite regularly to get information about science. However, with regard to their patterns of online media use about science and research, they differ from the "Active Seekers". They use online media considerably less, as their use of Facebook, blogs or Youtube is among the lowest of the five 
segments. If they use online sources at all, their focus is on websites of scientific institutions, Wikipedia, and news media outlets online.

- People in the "Alternative Online Media Users" segment $(n=221,21.02 \%)$ do not get in contact with science in traditional media that often. When they do, they use newspapers (online and offline) for information about science, however, they barely use specific outlets focusing on science such as magazines. At the same time, their use of online media differs from the other segments. Their use of mainstream online media sources is not so pronounced but they use alternative channels of information on the Internet instead. People belonging to this segment get in contact with information about science and research when using Wikipedia and Youtube.

- The fourth segment, the "Occasional Information Seeker" ( $\mathrm{n}=191,18.19 \%)$, only sporadically gets information about science when they use TV or print media. Their use of online media about science is at a comparatively low level. If at all, they use Wikipedia to look up information. However, compared to the other segments even the use of Wikipedia is at a lower level.

- Compared to all the other segments, the "Non-Users" $(n=224,21.34 \%)$ hardly get into contact with information about science and research. Strikingly, the second largest segment of the Swiss population does not get in contact with information about science in online media at all. They get in touch with scientific information when they use television and traditional print media - their science media use patterns completely belong to the offline world, likely as a by-product of habitual media use.

For Germany, identifying the best fitting model was more complicated: Although the BIC pointed to a 10-segment model as the preferred choice (see online appendix), that particular solution was difficult to interpret. The six-segment model - as well as all higher 
models - already raised several questions regarding the explanatory value of its segments: For one, they strongly differed in size, with the smallest one covering only $9 \%$ of the respondents (5\% in the higher models); for another, their profiles were almost indistinguishable and resulted in identical interpretations. We therefore opted for the five-segment solution, which had reasonable population shares (15\% - 27\%) and five distinct profiles (see Figure 2 and Table 3 of the Appendix). The hitrate of this segmentation was $\mathrm{T}=0.85$ (cf. Gollwitzer, 2012) and for $99 \%$ of the cases, the posterior probability exceeded $40 \%$. No single case was indecisive.

Figure 2

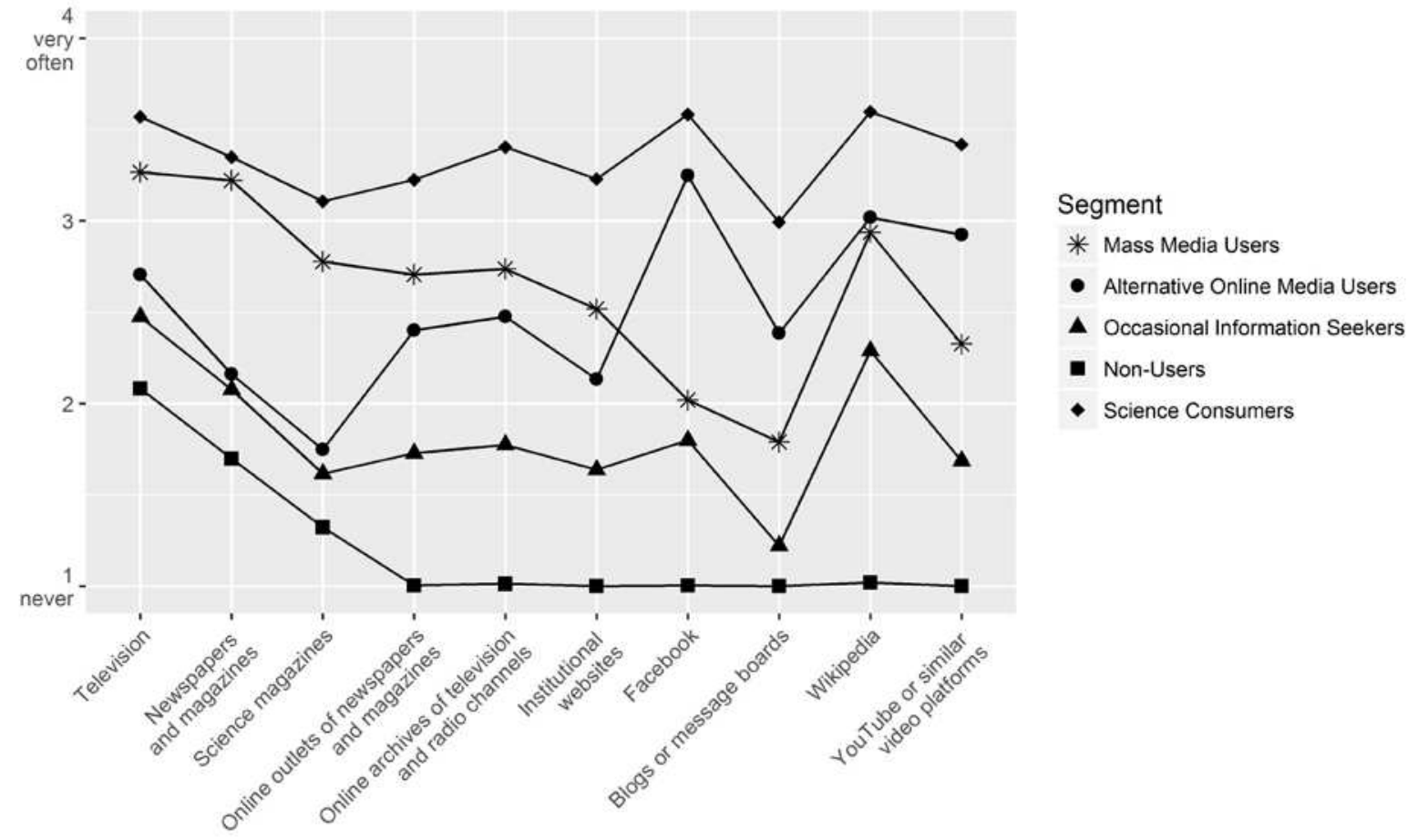

- We could identify a segment of "Science Consumers" $(n=293,14.7 \%)$. Similar to the "Active Seekers" in Switzerland, this segment shows the highest use of scientific information across all media channels, including online communication. However, compared to the Swiss "Active Seekers", people in this segment also clearly have the highest contact with science through traditional mass media. In addition, their use of Facebook for scientific information is strong, also constituting a difference from the 
"Active Seekers" in Switzerland who use Wikipedia and Youtube more often than social networks.

- The second segment are the "Mass Media Users" $(n=478,23,94 \%)$. They also show generally high levels of science information use but they get in contact with scientific issues primarily via television and print media more than via online media. If they look for scientific information online, they do so in online outlets of newspapers or online archives of television and radio channels or on websites of scientific institutions, for which they yield the second highest scores within the German public.

- In contrast to the "Mass Media Users", the segment of the "Alternative Online Media Users" $(\mathrm{n}=478,23,92 \%)$ is more oriented towards the use of information about science on the Internet. While they do not get in contact with scientific information that often through traditional mass media, they are much more active online, especially using alternative information sources. They yield the second highest scores for the use of Facebook, Wikipedia, Youtube and blogs. Facebook is even their most frequently used source of information.

- We also find a segment of "Occasional Information Seekers" in Germany ( $n=433$, $21.68 \%)$. People in this segment show average patterns of information use with regard to science. They occasionally get in contact with science through television and online media at a lower level. They almost never get in contact with scientific information through blogs but they use Wikipedia from time to time.

- The last segment of the German population are also the "Non-Users" ( $n=315,15.77 \%)$. Like in Switzerland, German citizens in this segment do not use online media for scientific information at all. If they get in contact with information about science, it is through television. 
Since we find five segments in both countries, which are very much comparable (see also Figure 3), we find some initial evidence for Hypothesis 4. What is more, these segments differ in their frequency of information use about science with the "Active Seekers"/ "Science Consumers" being the ones informing themselves about science most regularly, thus supporting Hypothesis $1 \mathrm{~b}$. The segments can also be distinguished with regards to their use of offline and online media. The fact that we find segments such as the "Alternative Online Media Users" and the "Mass Media Users" supports Hypothesis 1a.

\section{Sociodemographic and Attitudinal Characteristics of the Segments}

The identified segments in both countries differ with regards to sociodemographics and science-related attitudes (Table 2, Figure 3). In both countries, the "Active Seekers" and "Science Consumers" are highly educated, have a relatively high scientific literacy and the highest trust and interest in science, thus corroborating Hypothesis $2 \mathrm{c}$ and 3. Also, with regards to contact with science and research on other occasions (e.g. visits in museums and zoos), these segments yield the highest scores in both countries. In the segment of the "NonUsers", we find in both countries considerably more women than men, and the level of education is the lowest compared to all other segments in both countries. This corresponds to a low level of scientific literacy. People in this segment also trust science the least, have the lowest interest and are least likely to get in contact with science and research at other occasions (e.g. visiting museums etc.).

The other segments are positioned between the "Active Seekers"/ "Science Consumers" and the "Non-Users" with regards to their sociodemographics and attitudes towards science. The "Mass Media Users" in Switzerland and Germany are quite similar to the "Active Seekers"/ "Science Consumers" in that they are highly educated and show high scientific literacy. The "Alternative Online Media Users" are the youngest segment on 
average. This lends support to Hypothesis 2a. Instead, we do not find evidence for Hypothesis $2 \mathrm{~b}$, as the "Alternative Online Media Users" are balanced in gender. Apart from these similarities, we also recognize some differences in the sociodemographic characteristics and attitudes towards science between the German and Swiss segments. In Switzerland, "NonUsers" are the oldest segment, while in Germany, the "Mass Media Users" are the oldest overall. In Switzerland, the "Non-Users" are the most religious on average, which is not the case in Germany. Figure 3 provides an overview of all segments in Switzerland and Germany and their distinct media repertoires, attitudes towards science, and socio-demographic characteristics.

\section{[Table 2 about here]}




\begin{tabular}{|c|c|}
\hline Switzerland & Germany \\
\hline 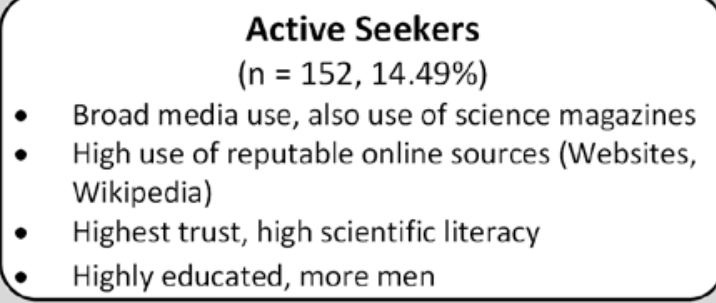 & \begin{tabular}{l}
\multicolumn{1}{c}{ Science Consumers } \\
$(n=293,14.7 \%)$ \\
- $\quad$ Highest use of all media channels, including \\
online sources \\
- $\quad$ High use of social media (Facebook) \\
Highest trust, high scientific literacy \\
Highly educated, balanced gender distribution
\end{tabular} \\
\hline $\begin{array}{l}\text { Mass Media Users } \\
\qquad(\mathrm{n}=262,24.96 \%) \\
\text { - } \quad \text { Highest use of traditional mass media } \\
\text { - } \quad \text { High trust, highest scientific literacy } \\
\text { - } \quad \text { Highly educated }\end{array}$ & $\begin{array}{l}\text { Mass Media Users } \\
\qquad(\mathrm{n}=478,23,94 \%) \\
\text { - } \quad \text { Frequent use of traditional mass media } \\
\text { - } \quad \text { High trust, highest scientific literacy } \\
\text { - } \quad \text { Highly educated, oldest segment }\end{array}$ \\
\hline $\begin{array}{l}\text { Alternative Online Media Users } \\
\qquad \begin{array}{l}\multicolumn{1}{c}{(\mathrm{n}=221,21.02 \%)} \\
\text { - }\end{array} \\
\text { - } \text { Modequente use of traditional mass media } \\
\text { a lower level } \\
\text { Moderate trust, interest, and literacy } \\
\text { Youngest segment }\end{array}$ & $\begin{array}{l}\text { Alternative Online Media Users } \\
\qquad(n=478,23,92 \%) \\
\text { - } \quad \text { Moderate use of traditional mass media } \\
\text { - } \text { Wighest use of Facebook, frequent use of } \\
\text { - Moderate trust, interest, and literacy } \\
\text { Youngest segment }\end{array}$ \\
\hline $\begin{array}{l}\text { Occasional Information Seeker } \\
\qquad(\mathrm{n}=191,18.19 \%) \\
\text { - } \quad \text { Only sporadic use of TV or print media } \\
\text { - Wittle use of online media (moderate use of } \\
\text { - Moderate trust, interest, and literacy } \\
\text { Medium age, gender balanced }\end{array}$ & $\begin{array}{l}\text { Occasional Information Seeker } \\
\qquad \begin{array}{l}(n=433,21.68 \%) \\
\text { - }\end{array} \\
\text { - } \quad \text { Little use of blogs or social media (moderate use } \\
\text { of Wikipedia) } \\
\text { - Moderate trust, interest, and literacy } \\
\text { Second oldest segment }\end{array}$ \\
\hline $\begin{array}{l}\text { Non-Users } \\
\qquad(\mathrm{n}=224,21.34 \%) \\
\text { - } \quad \text { Hardly any science-related information use } \\
\text { - } \quad \text { use of online media } \\
\text { - } \quad \text { More women, less educated, oldest segment }\end{array}$ & $\begin{array}{l}\text { Non-Users } \\
\qquad(n=315,15.77 \%) \\
\text { - } \quad \text { Mordly any science-related information use } \\
\text { - } \quad \text { no use of online media } \\
\text { - } \quad \text { Mow trust, interest, and literacy } \\
\end{array}$ \\
\hline
\end{tabular}

\section{Discussion}

Our study demonstrates that segments of the population can be distinguished with regards to their science-related information use, thus providing evidence about people's media repertoires for science. We find a spectrum of information user segments ranging from those who inform themselves frequently and actively about science and research ("Active Seekers"/ "Science Consumers") to those who hardly get in contact with information about science at all 
("Non-Users"). In between, there are segments which receive information about science and research through their habitual media use or sporadically inform themselves ("Occasional Information Seekers"). What is more, audience segments differ with regard to their preference of online or offline media, or, more precisely, mainstream or alternative sources of information. The "Alternative Online Media Users" retrieve specific online media, among them social media and blogs, more than all the other segments (with the exception of the "Science Consumers"). The "Mass Media Users" do not refrain from using online media, but they use established and journalistic sources on the Internet more often than alternative sources like social media. Overall, the study shows that audience segments of science communication which we find in one country, i.e. Switzerland, can be found almost equally in another country, i.e. Germany, which is very similar in its media system and with regards to media coverage about science and science journalism.

In both countries, the segments are also very similar with regards to their sociodemographics and attitudes towards science. Their media use is reflected in their attitudes towards science - those segments which get in contact with information about science and research frequently show generally more positive attitudes. We also find wellestablished trends with regard to the sociodemographic profiles of the segments. Those segments, which actively inform themselves about science ("Active Seekers" / "Science Consumers"), are more highly educated. The "Alternative Online Media Users" are also the youngest segment on average (Nisbet et al., 2002).

However, we also find some nuanced differences between the two countries. In Germany, Facebook is a much more common source for information about science than in Switzerland. For the "Alternative Online Media Users" in Germany it is even the most important information source. It has to be noted though, that this can also be due to the fact 
the the German sample relied on an online panel. At the same time, Youtube seems to play a greater role in the online environment for scientific information in Switzerland.

The general differences between the audience segments replicate what has been found for general news media use (e.g. Mangold et al., 2017; Schneier \& Eisenegger, 2016). Some segments are more inclined towards online media use while others lean more towards traditional mass media. However, if one takes a deeper look at the findings they also reveal that there are differences between audience segments of general news media use and audience segments of science information use. The significance of Wikipedia for almost all segments is something that is not found when audience segments of general news use are concerned. The relevance of Wikipedia for science communication has been also established in other studies (e.g. Segev \& Sharon, 2017). In addition, institutional websites play a less important role in citizens' information repertoires when they inform themselves about everyday or political news. That the segments identified in this study are science-specific is underscored by the fact that science magazines constitute one of the distinguishing variables. There is a clear difference in the use of science magazines between the "Active Seekers"/ "Science Consumers" and "Mass Media Users" compared to the other three segments in both countries. This exemplifies the relevance of special interest media for scientific information. We can compare our findings to the clusters found by Guenther \& Weingart (2018) in South Africa although they did not conduct their analysis solely based on media use variables. They found two clusters which use scientific information frequently. People belonging to the "Urban, moderately literate and moderately educated" cluster use mostly television and could be roughly compared to the "Mass Media Users" in Germany and Switzerland (Guenther \& Weingart, 2018). The other group "Urban, moderately to high literate, and highly educated" also frequently use the Internet but it is not clear what exactly they use online. Thus, we cannot establish whether they are comparable to the "Alternative Online Media Users" since 
those rely on non-journalistic online sources such as Youtube. Therefore, our study allows for a more detailed analysis of the science-specific media use since it incorporate various online channels.

The characteristics of the audience segments have some implications for science communication. First, the segment of the "Non-Users" is quite large in Switzerland, and of considerable size in Germany. There is a significant part of the population in both countries which rarely or never gets in contact with science-related media content. Since this is combined with little interest and lower education, the question is how to reach this segment of the public. If the "Non-Users" get in contact with information about science and research at all, this happens through traditional journalistic mass media, namely television and newspapers or magazines. This underlines that traditional science journalism is still important since those who do not search for information about science actively at least get in touch with it through their habitual media use.

Second, the other important result of our segmentation analysis is that online media play an important role for audiences. The "Alternative Online Media Users" entails between 21 and 24 percent of the population in both countries. A significant number of people use scientific information which has not, or only partly, passed the journalistic quality criteria. This raises the question how science should deal with this situation. On the one hand, this is an opportunity for science communicators since they can reach a large part of the audience directly. On the other hand, they also have to deal with the risk that these people encounter information online which they think are scientific but may include pseudo-scientific information (Authors, 2017). Science communicators thus need to develop strategies to deal with this, for example, by cooperating with other partners in the educational sector. This study provides a first basis for such strategic considerations by outlining what media are used by different audience segments. 
Third, although the "Active Seekers" in Switzerland generally use scientific information very regularly, their frequent use of Wikipedia could pose a problem to science communicators. If even the "Active Seekers" look for scientific information most frequently on Wikipedia, the question is how science communicators may reach these people, who are highly interested in science and probably open to their messages, with targeted information.

Fourth, one has to keep in mind that science media use is also driven by people's motives why they use specific media outlets. For science communicators, it is not only relevant what kind of information repertoires exist in the public but also what the drivers behind the various kinds of media use are. Only if they know whether citizens use certain science media for information, entertainment, habitual use, or one of the many other motives, they gain a better understanding on how to reach these segments. Future studies could thus build upon this study and highlight what motives drive which audience segments.

Comparing audience segments in two countries with very similar media systems and similar structures regarding science communication, we aimed at overcoming the specificity of one nation state. Our hypothesis that similar communication environments should yield similar audience structures finds general support. However, this analysis is only a first step in the attempt to link science communication structures and science information usage and needs to be extended to other countries and cultures. In this vein, it will be especially necessary to analyze the relevance of alternative online media, which operate independently from the formal media and information systems and are accessible for users across countries with the potential to create online audience segments independent from geographic boundaries. Of course, the ongoing development of online communication and related changes in patterns of usage should also be observed on a longitudinal basis.

And last, it is well possible that science information usage is dependent on 1) aspects of specific scientific topics or domains and 2) individual factors on the side of the recipient as 
well as 3) interactions of both types of variables. For example, controversial scientific issues could spark more intense and diversified media use in general. Also, one can easily imagine that someone is an "Active Seeker" or "Science Consumer" when it comes to a specific scientific topic which she/ he is particularly interested in or affected by (e.g. with regards to health issues). At the same time, this person may belong to the segment of the "Non-Users" when other scientific topics are concerned which she/ he has no interest in (e.g. astronomy). Our segmentation analysis cannot account for such differences regarding topics nor intraindividual preferences, but by looking at general science information use it is able to provide information on audience segments which are valuable for providers of a broad spectrum of science information, e.g. mass media but also actors in the educational sector.

Related to this limitation of the study, although we identify the different science information repertoires of the public we cannot say anything about how the use of a certain type of channel is interrelated with the use of other information sources from a procedural perspective and on an individual basis. For example, it is possible that individuals get in contact with a scientific issue through mass media coverage and subsequently look for more information about this issue on Wikipedia. 


\section{References}

Anderson, A. A., Scheufele, D. A., Brossard, D., \& Corley, E. A. (2012). The Role of Media and Deference to Scientific Authority in Cultivating Trust in Sources of Information about Emerging Technologies. International Journal of Public Opinion Research, 24(2), 225-237. https://doi.org/10.1093/ijpor/edr032

BBVA Foundation. (2011). International Study on Scientific Culture: Understanding of Science. Bilbao: BBVA.

Besley, J. C. (2013). The state of public opinion research on attitudes and understanding of science and technology. Bulletin of Science, Technology \& Society, 0270467613496723.

Besley, J. C. (2016). The National Science Foundation's Science and Technology Survey and Support for Science Funding, 2006-2014. Public Understanding of Science. Advance online publication. https://doi.org/10.1177/0963662516649803

Brossard, D. (2013). New media landscapes and the science information consumer. Proceedings of the National Academy of Sciences of the United States of America, 110 Suppl 3, 14096-14101. https://doi.org/10.1073/pnas.1212744110

Büchi, M. (2017). Microblogging as an Extension of Science Reporting. Public Understanding of Science, 26(8), 953-968. https://doi.org/10.1177/0963662516657794

Chang, J.-H., Kim, S.-H., Kang, M.-H., Shim, J. C., \& Ma, D. H. (2017). The Gap in Scientific Knowledge and Role of Science Communication in South Korea. Public Understanding of Science. Advance online publication. https://doi.org/10.1177/0963662516685487 
Dibb, S., \& Simkin, L. (2009). Bridging the Segmentation Theory/Practice Divide. Journal of Marketing Management, 25(3-4), 219-225. https://doi.org/10.1362/026725709X429728

Dingerkus, F., Keel, G. \& Wyss, V. (2016). Country Report: Journalists in Switzerland (World of Journalism Study). Retrieved from urn:nbn:de:bvb:19-epub-30991-7

Dudo, A., Brossard, D., Shanahan, J., Scheufele, D. A., Morgan, M., \& Signorielli, N. (2011). Science on Television in the 21st Century. Communication Research, 38(6), 754-777. https://doi.org/10.1177/0093650210384988

Eisenegger, M., \& Gedamke, S. (2013). Wissenschaft in den Medien. Zur Logik medialer Wissenschaftsvermittlung. medien \& zeit, 28(4), 34-45.

Esser, F., \& Hanitzsch, T. (2012). On the Why and How of Comparative Inquiry in Communication Studies. In F. Esser \& T. Hanitzsch (Eds.), Handbook of Comparartive Communication Research (pp. 3-22). New York: Routledge.

Eurobarometer. (2010). Special Eurobarometer 340: Science and Technology. Brussels: European Commission.

fög - Forschungsinstitut Öffentlichkeit und Gesellschaft / Universität Zürich. (2017). Jahrbuch 2017: Qualität der Medien. Basel: Schwabe Verlag.

Gollwitzer, M. (2012). Latent-Class-Analysis. In H. Moosbrugger \& A. Kelava (Eds.), Springer-Lehrbuch. Testtheorie und Fragebogenkonstruktion (2nd ed., pp. 295-323). Berlin, Heidelberg: Springer Berlin Heidelberg.

Guenther, L., \& Weingart, P. (2018). Promises and Reservations towards Science and Technology among South African Publics: A culture-sensitive approach. Public Understanding of Science, 27(1), 47-58. https://doi.org/10.1177/0963662517693453 
Hallin, D. C., \& Mancini, P. (2004). Comparing Media Systems: Three Models of Media and Politics. Communication, society and politics. Cambridge: Cambridge University Press.

Hanitzsch, T., Steindl, N., \& Lauerer, C. (2016). Country Report: Journalists in Germany (World of Journalism Study). Retrieved from urn:nbn:de:bvb:19-epub-28095-3

Hanusch, F., \& Hanitzsch, T. (2017). Comparing Journalistic Cultures Across Nations. Journalism Studies, 18(5), 525-535. https://doi.org/10.1080/1461670X.2017.1280229

Hasebrink, U., \& Popp, J. (2006). Media Repertoires as a Result of Selective Media Use. A Conceptual Approach to the Analysis of Patterns of Exposure. Communications, 31 (3), 369-387.

Hine, D. W., Reser, J. P., Morrison, M., Phillips, W. J., Nunn, P., \& Cooksey, R. (2014). Audience Segmentation and Climate Change Communication: Conceptual and methodological considerations. Wiley Interdisciplinary Reviews: Climate Change, 5(4), 441-459. https://doi.org/10.1002/wcc.279

Hömberg, W., \& Yankers, M. (2000). Wissenschaftsmagazine im Fernsehen. Exemplarische Analysen öffentlich-rechtlicher und privater Wissenschaftssendungen. Media Perspektiven. (12), 574-580. Retrieved from http://www.ardwerbung.de/fileadmin/user_upload/media-perspektiven/pdf/2000/122000_Hoemberg.pdf

Jia, H., Wang, D., Miao, W., \& Zhu, H. (2017). Encountered but Not Engaged: Examining the Use of Social Media for Science Communication by Chinese Scientists. Science Communication, 39(5), 646-672. https://doi.org/10.1177/1075547017735114

Kawamoto, S., Nakayama, M., \& Saijo, M. (2013). A Survey of Scientific Literacy to Provide a Foundation for Designing Science Communication in Japan. Public Understanding of Science, 22(6), 674-690. https://doi.org/10.1177/0963662511418893 
Lee, C.-j., Scheufele, D. A., \& Bruce V. Lewenstein. (2005). Public Attitudes toward Emerging Technologies: Examining the Interactive Effects of Cognitions and Affect on Public Attitudes toward Nanotechnology. Science Communication, 27(2), 240-267.

Linzer, D. A., \& Lewis, J. B. (2011). poLCA: An R Package for Polytomous Variable Latent Class Analysis. Journal of Statistical Software, 42(10), 1-29. https://doi.org/10.18637/jss.v042.i10

Livingstone, S. (2003). On the Challenges of Cross-National Comparative Media Research. European Journal of Communication, 18(4), 477-500.

Lotenberg, L. D., Schechter, C., \& Strand, J. (2011). Segmentation and Targeting. In G. Hastings, K. Angus, \& C. Bryant (Eds.), The Sage Handbook of Social Marketing (pp. 125-135). Thousand Oaks: SAGE.

Magidson, J., \& Vermunt, J. (2004). Latent Class Models. In D. Kaplan (Ed.), The Sage Handbook of Quantitative Methodology for the Social Sciences (pp.175-198). Thousand Oaks: SAGE.

Maibach, E. W., Weber, D., Massett, H., Hancock, G. R., \& Price, S. (2006). Understanding Consumers' Health Information Preferences: Development and Validation of a Brief Screening Instrument. Journal of health communication, 11(8), 717-736. https://doi.org/10.1080/10810730600934633

Mangold, F., Vogelgesang, J., \& Scharkow, M. (2017). Nachrichtennutzung in Deutschland. Eine nutzerzentrierte Repertoireanalyse. Medien \& Kommunikationswissenschaft, 65(4), 704-723. https://doi.org/10.5771/1615-634X-2017-4-704

McLachlan, G. J., \& Peel, D. (2005). Finite Mixture Models. Wiley series in probability and statistics Applied probability and statistics section. New York: Wiley. 
Mejlgaard, N. (2017). Science's Disparate Responsibilities: Patterns across European Countries. Public Understanding of Science. Advance online publication. https://doi.org/10.1177/0963662517724645

Milde, J., \& Ruhrmann, G. (2006). Molekulare Medizin in deutschen TV-

Wissenschaftsmagazinen.Ergebnisse von Journalisteninterviews und Inhaltsanalysen. Medien \& Kommunikationswissenschaft, 54(3), 430-456.

Nisbet, M. C., Scheufele, D. A., Shanahan, J., Moy, P., Brossard, D., \& Lewenstein, B. V. (2002). Knowledge, Reservations, or Promise? A Media Effects Model for Public Perceptions of Science and Technology. Communication Research, 29(5), 584-608. https://doi.org/10.1177/009365002236196

OST, \& Wellcome Trust. (2000). Science and the Public: A Review of Science Communication and Public Attitudes to Science in Britain. London: The Office of Science and Technology (OST) \& Wellcome Trust.

OST, \& The Wellcome Trust. (2001). Science and the public: A review of science communication and public attitudes toward science in Britain. Public Understanding of Science, 10(3), 315-330.

OST. (2005). Science in Society: Findings from Qualitative and Quantitative Research. London: Department of Trade \& Industry, Office of Science and Technology. Pew Research Center. (2013). Public's Knowledge of Science and Technology. Retrieved from http://www.people-press.org/2013/04/22/publics-knowledge-of-science-andtechnology/

Reitze, H. (2016). Media Perspektiven: Basisdaten 2016. Retrieved from http://www.ardwerbung.de/fileadmin/user_upload/mediaperspektiven/Basisdaten/Basisdaten_2016_Inhalt_komplett_verlinkt.pdf 
Research Councils UK. (2008). Public Attitudes to Science 2008: A Survey. London:

Department of Innovation, Universities \& Skills.

Scheufele, D. A., \& Lewenstein, B. V. (2005). The Public and Nanotechnology: How Citizens Make Sense of Emerging Technologies. Journal of Nanoparticle Research, 7(6), 659667. https://doi.org/10.1007/s11051-005-7526-2

Schneider, J., \& Eisenegger, M. (2016). Wie Mediennutzer in die Welt schauen: Die Newsrepertoires der Schweizerinnen und Schweizer und ihre Themenagenden: Studie 2/2016. In fög - Forschungsinstitut Öffentlichkeit und Gesellschaft / Universität Zürich (Ed.), Studien Qualität der Medien. Basel: Schwabe Verlag.

Segev, E., \& Sharon, A. J. (2017). Temporal Patterns of Scientific Information-seeking on Google and Wikipedia. Public understanding of science (Bristol, England), 26(8), 969-985. https://doi.org/10.1177/0963662516648565

Slater, M. D. (1996). Theory and Method in Health Audience Segmentation. Journal of health communication, 1(3), 267-283. https://doi.org/10.1080/108107396128059

Smith, W., R. (1956). Product Differentiation and Market Segmentation as Alternative Marketing Strategies. Journal of Marketing, 21(1), 3-8.

Steindl, N., Lauerer, C., \& Hanitzsch, T. (2017). Journalismus in Deutschland. Publizistik, 62(4), 401-423. https://doi.org/10.1007/s11616-017-0378-9

Su, L. Y.-F., Scheufele, D. A., Bell, L., Brossard, D., \& Xenos, M. A. (2017). InformationSharing and Community-Building: Exploring the Use of Twitter in Science Public Relations. Science Communication, 39(5), 569-597. https://doi.org/10.1177/1075547017734226

Sütterlin, B., Brunner, T. A., \& Siegrist, M. (2011). Who puts the most energy into energy conservation? A segmentation of energy consumers based on energy-related 
behavioral characteristics. Energy Policy, 39(12), 8137-8152.

https://doi.org/10.1016/j.enpol.2011.10.008

Vermunt, J., \& Magidson, J. (2016). Technical Guide for Latent GOLD 5.1: Basic, Advanced, and Syntax. Belmont: Statistical Innovations Inc.

Wissenschaft im Dialog (2016). Wissenschaftsbarometer 2016: Ergebnisse nach Subgruppen. Retrieved from https://www.wissenschaft-imdialog.de/fileadmin/user_upload/Projekte/Wissenschaftsbarometer/Dokumente_16/Wi ssenschaftsbarometer2016_nachSubgruppen.pdf

Yankelovich, D., \& Meer, D. (2006). Rediscovering Market Segmentation. Harvard Business Review, 84(2), 122-131, 166.

Zhao, X. (2009). Media Use and Global Warming Perceptions. Communication Research, 36(5), 698-723. https://doi.org/10.1177/0093650209338911 
Table 1 Overview of Measures

\begin{tabular}{|c|c|c|c|c|c|c|c|c|}
\hline \multirow[b]{2}{*}{ Media Sources } & \multicolumn{4}{|l|}{$\mathrm{CH}$} & \multicolumn{4}{|l|}{$\mathrm{DE}$} \\
\hline & Items & $\mathbf{N}$ & $\mathbf{M}$ & SD & Items & $\mathbf{N}$ & $\mathbf{M}$ & SD \\
\hline \multirow[t]{3}{*}{$\begin{array}{l}\text { How often do } \\
\text { you... }\end{array}$} & $\begin{array}{l}\text { get in contact with } \\
\text { science and } \\
\text { research via } \\
\text { television? }\end{array}$ & 1036 & 2.75 & 1.01 & $\begin{array}{l}\text { watch reports about } \\
\text { science and } \\
\text { research on } \\
\text { television? }\end{array}$ & 1986 & 2.82 & 0.85 \\
\hline & $\begin{array}{l}\text { get in contact with } \\
\text { science and } \\
\text { research via } \\
\text { newspapers or } \\
\text { magazines? }\end{array}$ & 1042 & 3.28 & 1.22 & $\begin{array}{l}\text { read articles about } \\
\text { scientific topics in } \\
\text { newspapers or } \\
\text { magazines? }\end{array}$ & 1978 & 2.49 & 0.96 \\
\hline & $\begin{array}{l}\text { get in contact with } \\
\text { science and } \\
\text { research via the } \\
\text { science pages of a } \\
\text { newspaper or } \\
\text { science } \\
\text { magazines? }\end{array}$ & 1032 & 1.95 & 1.28 & $\begin{array}{l}\text { read the science } \\
\text { pages of a } \\
\text { newspaper or } \\
\text { science magazines? }\end{array}$ & 1985 & 2.10 & 0.96 \\
\hline \multirow{7}{*}{$\begin{array}{l}\text { How often do you } \\
\text { get in contact } \\
\text { with science and } \\
\text { research via... }\end{array}$} & $\begin{array}{l}\text { Online outlets of } \\
\text { newspapers and } \\
\text { magazines }\end{array}$ & 1042 & 2.23 & 1.33 & & 1977 & 2.23 & 1.05 \\
\hline & $\begin{array}{l}\text { Online archives of } \\
\text { television and } \\
\text { radio channels }\end{array}$ & 1039 & 1.90 & 1.14 & & 1977 & 2.29 & 1.01 \\
\hline & $\begin{array}{l}\text { Institutional } \\
\text { websites } \\
\text { (scientific, } \\
\text { government, } \\
\text { organizations) }\end{array}$ & 1041 & 2.31 & 1.28 & & 1970 & 2.09 & 0.91 \\
\hline & $\begin{array}{l}\text { Facebook } \\
\text { (DE: and other } \\
\text { social media } \\
\text { networks) }\end{array}$ & 1044 & 1.55 & 1.06 & & 1978 & 2.33 & 1.21 \\
\hline & $\begin{array}{l}\text { Blogs or message } \\
\text { boards }\end{array}$ & 1042 & 1.54 & 0.90 & & 1975 & 1.86 & 0.93 \\
\hline & Wikipedia & 1040 & 2.72 & 1.40 & & 1977 & 2.61 & 1.08 \\
\hline & $\begin{array}{l}\text { YouTube or } \\
\text { similar video } \\
\text { platforms }\end{array}$ & 1043 & 2.22 & 1.29 & & 1979 & 2.28 & 1.04 \\
\hline $\begin{array}{l}\text { Other Contacts } \\
\text { with Science and } \\
\text { Research }\end{array}$ & & & & & & & & \\
\hline
\end{tabular}




\begin{tabular}{|c|c|c|c|c|c|c|c|c|}
\hline $\begin{array}{l}\text { How often do you } \\
\text { do one of the } \\
\text { following... }\end{array}$ & $\begin{array}{l}\text { Visit museums and } \\
\text { exhibitions } \\
\text { covering science } \\
\text { and research }\end{array}$ & 1049 & 2.47 & 1.08 & & 1988 & 2.02 & 0.85 \\
\hline & $\begin{array}{l}\text { Visit zoos, } \\
\text { aquariums or } \\
\text { botanical gardens }\end{array}$ & 1050 & 2.71 & 1.13 & & 1992 & 2.54 & 0.83 \\
\hline & $\begin{array}{l}\text { Attend events, } \\
\text { talks, discussions } \\
\text { concerning science } \\
\text { and research }\end{array}$ & 1050 & 2.09 & 1.09 & & 1989 & 1.70 & 0.81 \\
\hline & $\begin{array}{l}\text { Read nonfiction } \\
\text { books on science } \\
\text { and research }\end{array}$ & 1051 & 2.51 & 1.28 & & 1986 & 1.92 & 0.91 \\
\hline & $\begin{array}{l}\text { Watch movies } \\
\text { related to science } \\
\text { and research in the } \\
\text { cinema }\end{array}$ & 1049 & 2.32 & 1.18 & & 1967 & 2.60 & 0.85 \\
\hline & $\begin{array}{l}\text { Talk about science } \\
\text { and research with } \\
\text { friends and } \\
\text { acquaintances }\end{array}$ & 1051 & 3.11 & 1.12 & & 1986 & 2.46 & 0.92 \\
\hline $\begin{array}{l}\text { Scale format for } \\
\text { all items }\end{array}$ & $\begin{array}{l}1=" \text { "never" ... } \\
5=\text { "very often") }\end{array}$ & & & & $\begin{array}{l}\text { ( 1="never" ... } \\
\text { 4="very often") }\end{array}$ & & & \\
\hline \multicolumn{9}{|l|}{$\begin{array}{l}\text { Socio- } \\
\text { Demographics }\end{array}$} \\
\hline Age & Years & 1051 & 46.33 & 17.90 & & 1997 & 44.65 & 13.94 \\
\hline Gender & Percent female & 1051 & 50.76 & & & 1997 & 49.97 & \\
\hline Education & $\begin{array}{l}\text { Percent university } \\
\text { education }\end{array}$ & 1046 & 27.2 & & & 1997 & 15.77 & \\
\hline $\begin{array}{l}\text { Political } \\
\text { orientation }\end{array}$ & $\begin{array}{l}\text { (1="left" ... } \\
7=" \text { right") }\end{array}$ & 998 & 3.64 & 1.28 & $\begin{array}{l}\text { (1="left" ... } 11 \\
=\text { ="right") }\end{array}$ & 1779 & 5.55 & 2.15 \\
\hline Religiosity & $\begin{array}{l}(1=" \text { not at all } \\
\text { religious" .. 5=" } \\
\text { very religious") }\end{array}$ & 1047 & 2.72 & 1.25 & $\begin{array}{l}\text { „I would describe } \\
\text { myself as a } \\
\text { religous" (1=“" not } \\
\text { agree at all” ... } \\
\text { 4="completely } \\
\text { agree”) }\end{array}$ & 1974 & 1.88 & 0.98 \\
\hline $\begin{array}{l}\text { Proximity to } \\
\text { science }^{2}\end{array}$ & Index: 0-4 & 1049 & 1.59 & 1.26 & Index: 0-4 & 1896 & 0.74 & 0.97 \\
\hline
\end{tabular}

\footnotetext{
${ }^{2}$ Respondents were first asked whether they were scientists themselves. If not, they were asked whether they "personally knew a scientist", "have family members that study or studied at university level" or "come in
} 


\begin{tabular}{|c|c|c|c|c|c|c|c|c|}
\hline $\begin{array}{l}\text { Attitudes } \\
\text { towards Science } \\
\text { \& Research }\end{array}$ & & & & & & & & \\
\hline Interest in science & $\begin{array}{l}\text { How interested are } \\
\text { you in science and } \\
\text { research? } \\
\text { (1="not at all"... } \\
5=\text { "very } \\
\text { interested") }\end{array}$ & 1044 & 3.14 & 1.19 & $\begin{array}{l}\text { "I would describe } \\
\text { myself as interested } \\
\text { in science." (1=“" } \\
\text { not agree at all" ... } \\
\text { 4="completely } \\
\text { agree") }\end{array}$ & 1910 & 2.91 & 0.80 \\
\hline $\begin{array}{l}\text { Scientific } \\
\text { Literacy }\end{array}$ & $\begin{array}{l}\text { Index: } 0-8 \\
\text { Calculated from } 8 \\
\text { "true" or "false" } \\
\text { statements (e.g. } \\
\text { Electrons are } \\
\text { smaller than } \\
\text { atoms.) }\end{array}$ & 1051 & 5.95 & 1.47 & $\begin{array}{l}\text { Index: 0-8 } \\
\text { Calculated from } 8 \\
\text { "true" or "false" } \\
\text { statements (e.g. } \\
\text { Electrons are } \\
\text { smaller than } \\
\text { atoms.) }\end{array}$ & 1997 & 5.39 & 1.77 \\
\hline \multirow[t]{3}{*}{$\begin{array}{l}\text { How high is your } \\
\text { trust in...? }\end{array}$} & science in general & 1042 & 3.58 & 0.74 & & 1899 & 2.98 & 0.59 \\
\hline & $\begin{array}{l}\text { scientists from } \\
\text { universities }\end{array}$ & 1042 & 3.69 & 0.79 & & 1894 & 3.09 & 0.65 \\
\hline & $\begin{array}{l}\text { scientists from } \\
\text { private } \\
\text { corporations }\end{array}$ & 1041 & 3.13 & 0.90 & & 1886 & 2.45 & 0.78 \\
\hline $\begin{array}{l}\text { Format of trust } \\
\text { scales }\end{array}$ & $\begin{array}{l}\text { 1="very low" ... } \\
\text { 5="very high") }\end{array}$ & & & & $\begin{array}{l}\text { 1="very low" ... } \\
4=\text { ="very high") }\end{array}$ & & & \\
\hline
\end{tabular}

Obs.: The German item wording is only displayed, when differing from the Swiss version.

contact with science through their work". Each affirmative answers resulted in one index-point. Scientists were directly assigned four points, resulting in a sum-index ranging from 0 to 4. 
Table 2 Sociodemographics and Attitudes towards Science of the Segments

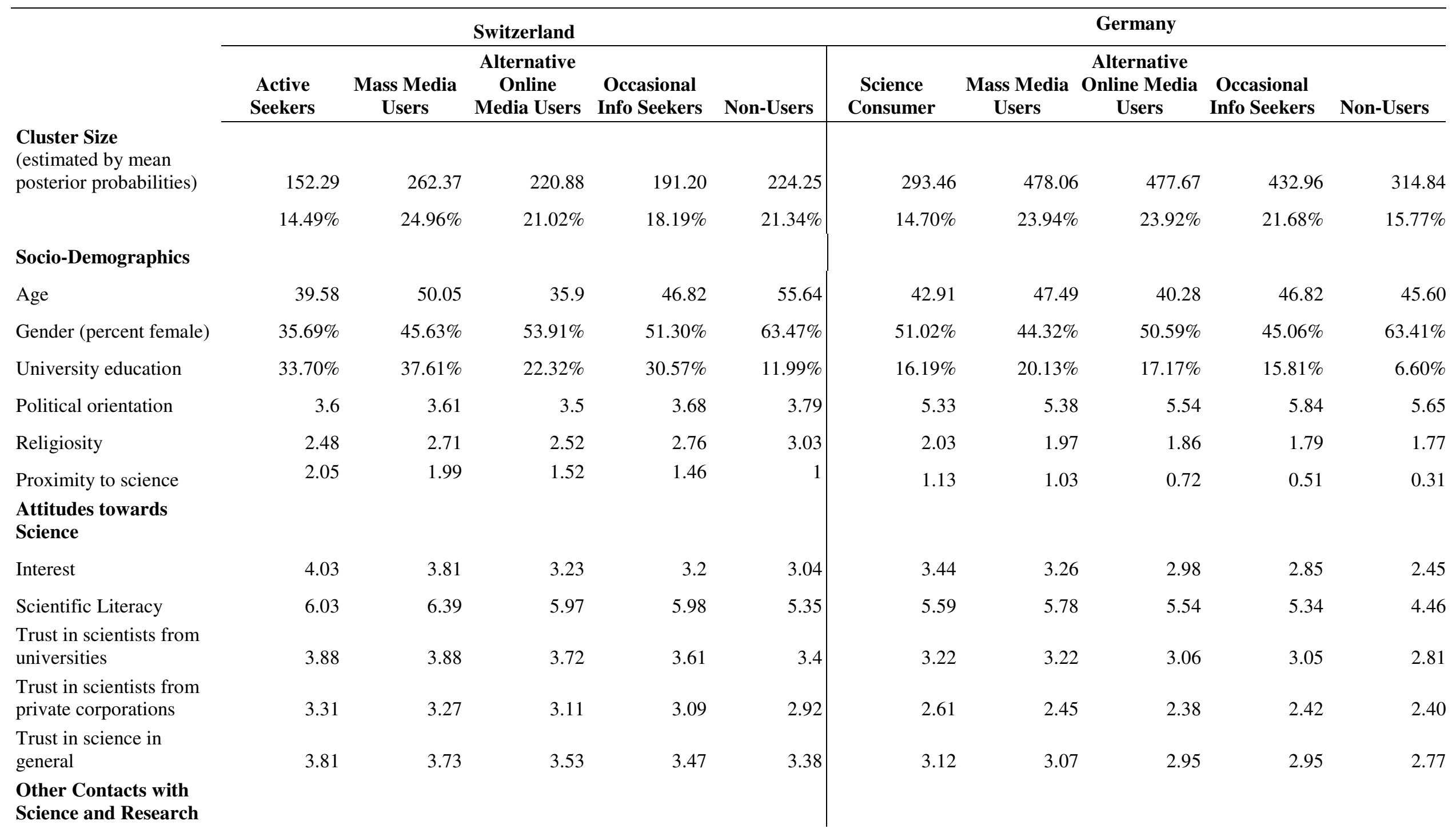


Museums and

exhibitions

Zoos, aquariums or

botanical gardens

Events, talks,

discussions

Nonfiction books

\section{Movies}

Talk with friends and acquaintances

$\begin{array}{rrrr}2.99 & 2.84 & 2.37 & 2.2 \\ 2.8 & 2.81 & 2.53 & 2.7 \\ 2.65 & 2.6 & 2 & 1.6 \\ 3.33 & 3 & 2.42 & 2.0 \\ 2.85 & 2.35 & 2.48 & 2.0 \\ 3.75 & 3.38 & 3.23 & 2.8\end{array}$

$\begin{array}{ll}2.24 & 1.99 \\ 2.73 & 2.66 \\ 1.67 & 1.55 \\ 2.04 & 1.86 \\ 2.09 & 1.98 \\ 2.81 & \end{array}$

1.99
2.66
1.55
1.86
1.98
2.5

2.67
2.99
2.50
2.86
3.
3.23

2.67

2.38

1.99

1.68

$\begin{array}{lllll}2.71 & 2.59 & 2.27 & 2.27\end{array}$

$\begin{array}{lllll}2.50 & 1.96 & 1.66 & 1.29 & 1.17\end{array}$

$\begin{array}{lllll}2.86 & 2.33 & 1.82 & 1.53 & 1.13\end{array}$

$\begin{array}{llllll}3.18 & 2.82 & 2.62 & 2.34 & 2.04\end{array}$

$\begin{array}{llll}3.23 & 2.85 & 2.54 & 2.11\end{array}$ 1.49 